\title{
ANALISIS KEPUASAN KONSUMEN TERHADAP PRODUK UNGGULAN SEKTOR MAKANAN KOTA MATARAM (STUDI PADA PRODUK TAHU ABIAN TUBUH)
}

\author{
M. Ilhamudin ${ }^{1}$, Santi Nururly ${ }^{2}$, Rusminah ${ }^{3}$ \\ ${ }^{1}$ Magister Manajemen Fakultas Ekonomi dan Bisnis, Universitas Mataram \\ E-mail: Ilham.alfian226@gmail.com \\ 2,3,4,5Fakultas Ekonomi dan Bisnis, Universitas Mataram
}

\section{ARTICLE INFO}

\section{Keywords :}

Konsumen, kepuasan, Tahu Abian

Tubuh

\section{Kata Kunci :}

Customers, satisfaction, Tahu Abian Tubuh.

\section{How to cite :}

Ilhamudin, M., Nururly, Santi., Rusminah., (2020). Analisis Kepuasan Konsumen Terhadap Produk Unggulan Sektor Makanan Kota Mataram

(Studi Pada Produk Tahu Abian Tubuh), 9(2), 134-148

DOI :

http://dx.doi.org/10.29303/jmm.v9i2.515

$\begin{array}{ll}\text { Dikumpulkan } & : 13 \text { Februari } 2020 \\ \text { Direvisi } & : 05 \text { Maret } 2020 \\ \text { Dipublikasi } & : 03 \text { Juni } 2020\end{array}$

\begin{abstract}
This research is aimed at determining the customers satisfaction towards a superior product of Mataram city, Tahu Abian Tubuh. The reseach is descriptive one which using sample survey method. In order to answer the problem proposed, the analytical tools are IKK model and Cartesius diagram. The first model is to measure a difference between what is desired and what is perceived by customers. The second model is to determine which are the attributes have priority to upgrade. The result of this study shows that customers are satisfied to the attributes of tahu Abian Tubuh. However, the flavor needs to have attention, due to the flavor of Tahu is fastly changed.
\end{abstract}

Penelitian ini bertujuan untuk mengetahui kepuasan konsumen pada salah satu produk unggulan sektor makanan kota Mataram, yaitu Tahu Abian Tubuh.

Penelitian ini merupakan penelitian deskriptif dengan menggunakan metode survey sampel. Untuk menjawab perumusan masalah, alat analisis yang digunakan adalah model IKK dan diagram Kartesius. Model pertama untuk mengukur perbedaan antara apa yang diinginkan dan dirasakan konsumen. Model kedua untuk menentukan atribut produk yang memiliki prioritas diperbaiki.

Hasil penelitian menunjukkan bahwa konsumen puas dengan produk Tahu Abian Tubuh. Meskipun demikian, atribut aroma perlu mendapat perhatian utama karena aroma produk ini cepat sekali berubah.

Copyright (C) 2020 JMM UNRAM. All rights reserved.

\section{PENDAHULUAN}

Sektor Usaha Mikro Kecil Menengah (UMKM) mempunyai peran yang besar dalam pembangunan ekonomi rakyat. Selain itu sektor ini juga berperan dalam meningkatkan pertumbuhan ekonomi secara nasional dan penyerapan tenaga kerja, dan menjadi mesin penggerak ekonomi lapisan masyarakat menengah kebawah. Perhatian pada pengembangan 


\section{Jurnal Magister Manajemen Unram Vol. 9, No 2. Juni 2020 NATIONALLY ACCREDITED JOURNAL - DECREE NO. 21/E/KPT/2018}

sektor UMKM memberikan makna tersendiri bagi usaha menekan angka kemiskinan dan bahkan dijadikan sebagai salah satu indikator keberhasilan pembangunan ekonomi. Ada tiga subsektor yang mempunyai kontribusi nilai produksi terbesar yaitu sektor industri makanan, minuman dan tembakau.

UMKM dalam sektor makanan salah satunya adalah industri tahu.Jumlah rata-rata konsumsi perkapita per minggu tahu nasionalmencapai jumlah tertinggi setiap tahunnya. Artinya bahwa minat masyarakat terhadap tahu lebih besar dari pada produk turunan kedelai yang lainnya.

Konsumsi produksi tahu akan berpengaruh terhadap kelangsungan hidup industri pengolahan kedelai, yang merupakan bahan baku pembuatan tahu. Di Kota Mataram memiliki beberapa industri pengolahan makanan yang berbasis kedelai. Ada beberapa tempat di Kota Mataram yang menjadi sentra industri berbasis kedelai (tahu-tempe) yaitu kawasan Abian Tubuh dan kawasan Kekalik Jaya, Tempit, Kebon Kopi, dan beberapa kawasan lainnya. Setiap kawasan memiliki jumlah unit usaha dan kontribusi yang berbeda. Dari beberapa sentra UMKM industri berbasis kedelai tersebut, kawasan Abian Tubuh disebut memiliki share produksi tahu yang paling besar diantara kawasan lain di Kota Mataram.

Berdasarkan Surat Keputusan Walikota Mataram Nomor 526/X/2009 tentang Penetapan Klaster Industri Kecil Unggulan Kota Mataram, maka industri tahu Abian Tubuh ditetapkan sebagai klaster industri/produkunggulan kota Mataram. Ada terdapat 227 unit usaha tahun 2015 dan tahun 2016 tidak bertambah, masih sebanyak 227 unit usaha. Perkembangan bisnis ini amat ditentukan oleh besarnya permintaan/konsumsi produk tersebut. Oleh karena itu, sebagai produsen tahu seharusnya memahami kebutuhan konsumen baik dalam konteks atribut produk agar produk tahu berkembang pesat yang akan berdampak pada besaran nilai penjualan sehingga tujuan perusahaan meraih keuntungan maksimal dapat dicapai. Penelitian yang dilakukan oleh Ilhamuddin(2018) menyebutkan bahwa produk tahu terdiri dari sejumlah atribut yaitu atribut citarasa, harga, warna, aroma, bentuk, tekstur, dan kandungan gizi.

Penelitian mengenai kepuasan konsumen sangat berperan dalam membantu perusahaan untuk mengetahui hal-hal yang diinginkan oleh konsumennya. Menurut Sumarwan (2003:123), konsumen memiliki keinginan akan suatu produk sesuai dengan pengetahuan yang dimilikinya, sehingga diharapkan produk tersebut dapat memberikan manfaat bagi konsumen. Jika produk yang dikonsumsi sesuai dengan apa yang diinginkan konsumen, maka konsumen akan mendapat kepuasan, dan akan melakukan pembelian sehingga kemudian dapat memberikan keuntungan bagi produsen atau pemasar.

Berdasarkan kondisi inilah penelitian tentang kepuasan konsumen ini penting untuk dilaksanakan demi keberlangsungan usaha industri tersebut yang pada gilirannya akan mampu menaikkan kesejahteraan pelaku industri sekaligus menggerakkan roda perekonomian di Kota Mataram.

\section{TINJAUAN TEORITIS}

\subsection{Kepuasan Konsumen}

Di dalam suatu proses keputusan, konsumen tidak hanya berhenti sampai proses konsumsi saja. Konsumen akan melakukan proses evaluasi terhadap konsumsi yang telah dilakukannya. Hasil dari proses evaluasi terhadap konsumsi yang telah dilakukannya adalah konsumen akan puas atau tidak puas terhadap konsumsi produk atau jasa yang telah dilakukannya. Setelah mengkonsumsi suatu produk atau jasa, konsumen akan memiliki perasaaan puas atau tidak puas terhadap produk atau jasa yang dikonsumsinya. Kepuasan akan mendorong konsumen membeli dan mengkonsumsi ulang produk atau jasa tersebut (Sumarwan, 2011). 


\section{Jurnal Magister Manajemen Unram Vol. 9, No 2. Juni 2020 NATIONALLY ACCREDITED JOURNAL - DECREE NO. 21/E/KPT/2018}

Menutur Kotler (dalam Lupiyoadi dan Hamdani, 2006: 158) kepuasan konsumen merupakan tingkat perasaan dimana seseorang menyatakan hasil perbandingan atas kinerja produk/jasa yang diterima dan yang diharapkan.Ini merupakan penilaian evaluatif pascapemilihan yang disebabkan oleh seleksi pembelian khusus dan pengalaman menggunakan barang atau jasa tersebut.

Sedangkan Gaspers (dalam Nasution, 2004) mengatakan bahwa kepuasan konsumen sangat bergantung kepada persepsi dan harapan konsumen. Adapun faktor-faktor yang mempengaruhi persepsi dan harapan konsumen antara lain:

1. Kebutuhan dan keinginan yang berkaitan dengan hal-hal yang dirasakan konsumen ketika sedang mencoba melakukan transaksi dengan produsen produk.

2. Pengalaman masa lalu ketika mengkonsumsi produk dari perusahaan maupun pesaingpesaingnya.

3. Pengalaman dari teman-teman.

Band (dalam Nasution, 2004) mengatakan bahwa kepuasan tercapai ketika kualitas memenuhi dan melebihi harapan, keinginan dan kebutuhan konsumen.Sebaliknya, bila kualitas tidak memenuhi dan melebihi harapan, keinginan dan kebutuhan konsumen maka kepuasan tidak tercapai. Konsumen yang tidak puas terhadap barang atau jasa yang dikonsumsinya akan mencari perusahaan lain yang mampu menyediakan kebutuhannya.

\subsection{Pengukuran Kepuasan Konsumen}

Dalam pengukuran tingkat kepuasan konsumen, ada beberapa aspek penting yang saling berkaitan. Meskipun demikian, di tengah beragamnya cara mengukur kepuasan konsumen, terdapat enam konsep inti apa yang harus diukur dari kepuasan konsumen tersebut menurut Tjiptono (2000: 101), yaitu:

1. Kepuasan konsumen keseluruhan (overall customer satisfaction). Cara yang paling sederhana untuk mengukur kepuasan konsumen adalah langsung menanyakan kepada konsumen seberapa puas mereka dengan produk atau jasa spesifik tertentu.

2. Dimensi Kepuasan Konsumen. Dimensi kepuasan konsumen merupakan penelitian memilah kepuasan konsumen ke dalam komponen-komponennya. Umumnya proses semacam itu terdiri atas empat langkah,yaitu: mengidentifikasi dimensi-dimensi kunci kepuasan konsumen, meminta konsumen menilai produk atau jasa perusahaan berdasarkan item-item spesifik seperti kecepatan layanan atau keramahan staf layanan konsumen, meminta konsumen menilai produk atau jasa pesaing berdasarkan item-item spesifik yang sama dan meminta para konsumenuntuk menentukan dimensi-dimensi yang menurut mereka paling penting dalam menilai kepuasan konsumen keseluruhan.

3. Konsirmasi Harapan (Confirmation of Expectation). Dalam konsep ini, kepuasan tidak diukur langsung, namun disimpulkan berdasarkan kesesuaian/ketidaksesuaian antara harapan konsumen dengan kinerja aktual produk perusahaan.

4. Minat pembelian ulang (repurchase intent). Minat pembelian ulang adalah kepuasan konsumen diukur secara behavioral dengan jalan menanyakan apakah konsumen akan berbelanja atau menggunakan jasa perusahaan lagi.

5. Kesediaan untuk merekomendasikan (willingness to recommend). Kesediaan konsumen untuk merekomendasikan produk kepada teman atau keluarga menjadi ukuran yang penting untuk dianalisis dan ditindaklanjuti.

6. Ketidakpuasan konsumen (customer dissatisfaction). Dilihat dari beberapa macam aspek yang sering ditelaah guna mengetahui ketidakpuasan konsumen, meliputi complain, return atau pengembalian produk, biaya garansi, recall, word of mouth negatif dan defections. 


\section{Jurnal Magister Manajemen Unram Vol. 9, No 2. Juni 2020 NATIONALLY ACCREDITED JOURNAL - DECREE NO. 21/E/KPT/2018}

\subsection{Faktor-faktor yang Mempengaruhi Kepuasan Konsumen}

Lupiyoadi dan Hamdani (2006) menyebutkan lima faktor utama yang perlu diperhatikan dalam kaitannya dengan kepuasan konsumen, antara lain:

1. Kualitas produk. Konsumen akan puas bila hasil evaluasi mereka menunjukkan bahwa produk yang mereka gunakan berkualitas. Produk dikatakan berkualitas bagi seseorang, jika produk itu dapat memenuhi kebutuhanya. Kualitas produk ada dua yaitu eksternal dan internal. Salah satu kualitas produk dari faktor eksternal adalah citra merek.

2. Kualitas pelayanan. Konsumen akan merasa puas bila mendapatkan pelayanan yang baik atau yang sesuai dengan harapan.

3. Emosional. Konsumen merasa puas ketika orang memuji dia karena menggunakan merek yang mahal.

4. Harga. Produk yang mempunyai kualitas yang sama tetapi menetapkan harga yang relatif murah akan memberikan nilai yang lebih tinggi.

5. Biaya. Konsumen yang tidak perlu mengeluarkan biaya tambahan atau tidak perlu membuang waktu untuk mendapatkan suatu produk atau jasa cenderung puas terhadap produk atau jasa tersebut.

\section{METODE PENELITIAN}

Jenis penelitian yang digunakan dalam penelitian ini adalah deskriptif. Dalam hal ini penelitian deskriptif digunakan untuk mendapatkan gambaran mengenai kepuasan konsumen terhadap produk unggulan kota Mataram yaitu tahu Abian Tubuh.

Dalam studi terhadap konsumen tahu Abian Tubuh, peneliti memilih 3 pasar tradisional. Peneliti memilih tiga pasar sebagai lokasi/tempat penelitian, yaitu:pertama, pasar Abian Tubuh, pasar ini dipilih karena lokasi pasar ini berada di sentra produksi tahu yang produknya diteliti;kedua, pasar Bertais karena merupakan pasar golongan A (besar) tempat berkumpul penjual dan pembeli dalam/luar kota yang terletak di pinggiran Kota Mataram; dan ketiga, pasar Dasan Agung, karena terletak di tengah pemukiman di dalam Kota Mataram.

Untuk mengetahui kepuasan konsumen, digunakan model Indeks Kepuasan Konsumen dan Diagram Kartesius. Indeks kepuasan konsumen (IKK) ini adalah membandingkan antara persepsi (perception) terhadap hasil (performance) suatu produk dengan harapannya (expectation). Bila kinerja produk dari pengalaman mengkonsumsi berada di bawah harapannya, kondisi ini menunjukkan hal tidak puas (dissatisfield), bila sama puas (satisfield), dan bila di atas sangat puas (highly satisfield).

Konsekuensi daripada definisi ini yaitu pengukuran kepuasan didasarkan kepada kesenjangan antara harapan dan pengalaman, tanpa harus mempermasalahkan dulu dimensi maupun indikator yang dijadikan ukuran kepuasan pelanggan. Secara implisit, konsep ini memenuhi asumsi bahwa responden sudah lebih dahulu mempunyai harapan atas barang dan jasa yang akan dikonsumsi, dan asumsi ini tidak selalu terpenuhi.

Rumus indeks kepuasan konsumen (IKK) adalah:

$$
\text { IndekKepuasanKonsumen }(I K K)=\frac{\text { KinerjaPasar }}{\text { HarapanKonsumen }}
$$

Formulasi tersebut memberikan makna sebagai berikut:

1. Apabila IKK $>1$, maka kualitas dikatakan tinggi.

2. Apabila IKK $=1$, maka kualitas dikatakan sedang.

3. Apabila IKK $<1$, maka kualitas dikatakan rendah. 
Selanjutnya hasil dari skala dianalisis dengan menggunakan interval.Interval pengukurannya merupakan perbandingan antara nilai tertinggi dikurangi nilai terendah dengan jumlah skala.

Selain model IKK, digunakan juga diagram kartesius, yaitu untuk mengetahui atributatribut produk yang perlu mendapat perhatian khusus, sehingga atribut atau dimensi tersebut dianggap penting oleh konsumen. Dalam diagram kartesius ini, persepsi kinerja dan derajat kepentingan dapat dilihat dari empat kuadran, yaitu kuadran I sampai kuadran IV, sehingga tampak setiap atribut yang dinilai konsumen terletak pada posisi di antara kuadran. Adapun bentuk gambar kartesius dapat dilihat pada gambar di bawah ini (Supranto, 2011: 242).

Kepentingan (Harapan) Konsumen

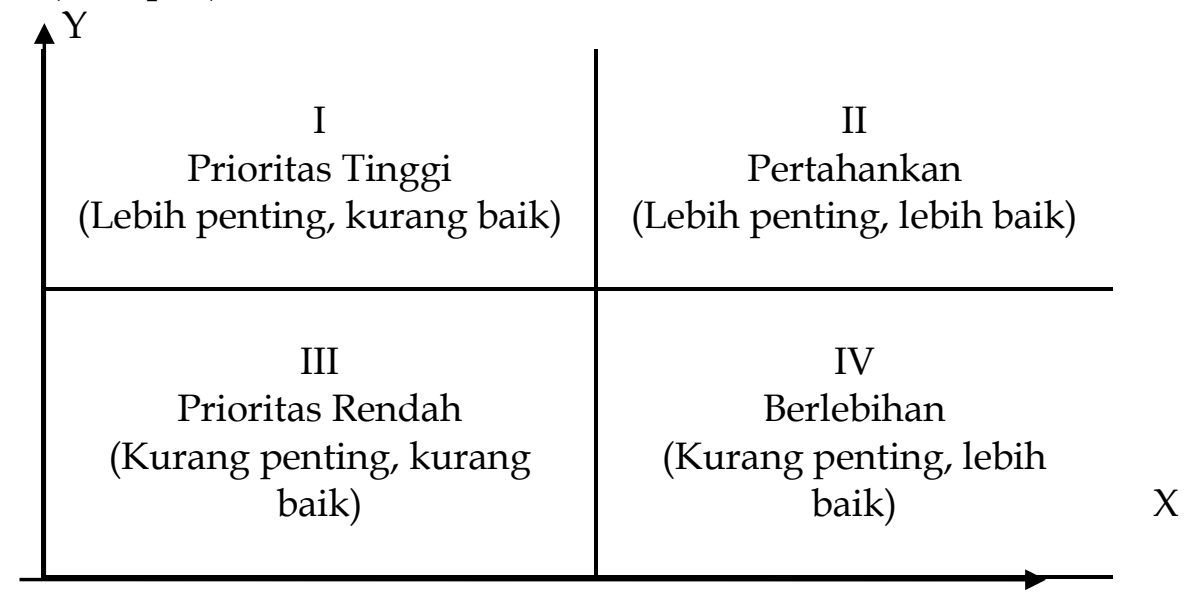

Kinerja Produk Tahu

Gambar 3.1. Diagram Kartesius

\section{HASIL DAN PEMBAHASAN}

\subsection{Analisis Harapan Konsumen dan Kinerja Produk Tahu Abian Tubuh}

Harapan konsumen merupakan pernyataan konsumen mengenai keinginan terhadap berbagai atribut yang melekat pada produk tahu Abian Tubuh.Keinginan terhadap atribut tersebut merupakan indikator hal yang perlu ditingkatkan. Sedangkan kinerja aktual merupakan pernyataan konsumen terhadap atribut atas apa yang dilihat, dirasakan maupun berdasarkan pengetahuan dan pengalamannya.

Dalam penelitian ini ada 7 (tujuh) atribut produk yang diukur, yaitu harga, cita rasa, warna, aroma, bentuk, tekstur, dan kandungan gizi untuk mengetahui persepsi atau tanggapan konsumen terhadap harapan dan kinerja produk tahu Abian Tubuh.Pengukuran kinerja dan harapan ini dilakukan dengan memberikan kuesioner kepada responden untuk diisi sesuai dengan pendapat mereka.Pengumpulan data dengan instrumen kuesioner dalam penelitian ini dilakukan pada bulan Mei - Juni 2019.Berikut diuraikan tingkat harapan dan kinerja produk tahu Abian Tubuh.

1. Harga Produk

Pada atribut harga terdapat perbedaan antara harapan konsumen dengan kenyataan yang ada pada produk (kinerja) sebagaimana ditunjukkan dalam tabel berikut. 


\section{NATIONALLY ACCREDITED JOURNAL - DECREE NO. 21/E/KPT/2018}

Tabel 4.9. Harapan Konsumen dan Kinerja Aktual pada Harga Tahu Abian Tubuh

\begin{tabular}{|c|l|c|c|c|c|c|}
\hline \multirow{2}{*}{ No } & \multirow{2}{*}{ Keterangan } & \multirow{2}{*}{ Skor } & \multicolumn{2}{|c|}{ Harapan } & \multicolumn{2}{c|}{ Kinerja } \\
\cline { 4 - 7 } & & Absolut & Jumlah & Absolut & Jumlah \\
\hline 1 & Sangat setuju & 5 & 20 & 100 & 46 & 230 \\
\hline 2 & Setuju & 4 & 35 & 140 & 38 & 152 \\
\hline 3 & Netral & 3 & 35 & 105 & 11 & 33 \\
\hline 4 & Tidak setuju & 2 & 10 & 20 & 5 & 10 \\
\hline 5 & $\begin{array}{l}\text { Sangat tidak } \\
\text { setuju }\end{array}$ & 1 & 0 & 0 & 0 & 0 \\
\hline Jumlah & & $\mathbf{1 0 0}$ & 365 & $\mathbf{1 0 0}$ & 425 \\
\hline Kriteria & \multicolumn{3}{|c|}{ Tinggi } & \multicolumn{2}{c|}{ Sangat Tinggi } \\
\hline
\end{tabular}

Sumber: data primer diolah

Pada tabel di atas dapat dilihat bahwa nilai harapan konsumen pada harga tahu sebesar 3,65 termasuk kriteria harapan tinggi. Nilai kinerja produk sebesar 4,25 adalah tergolong kriteria sangat tinggi. Ini berarti ada perbedaan nilai sebesar 0,60 yang berarti bahwa harga produk tahu telah memenuhi harapan konsumen.

2. Cita Rasa Produk

Cita rasa adalah unsur yang tidak dapat dilihat tetapi baru bisa diketahui setelah suatu produk makanan dicicipi sebagai menu hidangan.Pada unsur cita rasa ini hanya ada sedikit kesenjangan antara harapan konsumen dengan kenyataan yang ada pada produk.Nilai harapan dan kinerja dapat dilihat dalam tabel berikut.

Tabel 4.10. Harapan Konsumen Kinerja Aktual pada Cita Rasa Tahu Abian Tubuh

\begin{tabular}{|c|l|c|c|c|c|c|}
\hline \multirow{2}{*}{ No } & \multirow{2}{*}{ Keterangan } & \multirow{2}{*}{ Skor } & \multicolumn{2}{c|}{ Harapan } & \multicolumn{2}{c|}{ Kinerja } \\
\cline { 4 - 7 } & & & Absolut & Jumlah & Absolut & Jumlah \\
\hline 1 & Sangat setuju & 5 & 49 & 245 & 45 & 225 \\
\hline 2 & Setuju & 4 & 38 & 152 & 40 & 160 \\
\hline 3 & Netral & 3 & 9 & 27 & 11 & 33 \\
\hline 4 & Tidak setuju & 2 & 4 & 8 & 4 & 8 \\
\hline 5 & $\begin{array}{l}\text { Sangat tidak } \\
\text { setuju }\end{array}$ & 1 & 0 & 0 & 0 & 0 \\
\hline \multicolumn{2}{|c|}{ Jumlah } & & $\mathbf{1 0 0}$ & $\mathbf{4 3 2}$ & $\mathbf{1 0 0}$ & $\mathbf{4 2 6}$ \\
\hline \multicolumn{2}{|c|}{ Kriteria } & \multicolumn{2}{c|}{ Sangat tinggi } & \multicolumn{2}{c|}{ Sangat tinggi } \\
\hline
\end{tabular}

Sumber: data primer diolah 


\section{NATIONALLY ACCREDITED JOURNAL - DECREE NO. 21/E/KPT/2018}

Nilai harapan pada atribut cita rasa tahu adalah 4,32, dan nilai kinerja aktual adalah 4,26. Terdapat selisih 0,06 berarti hampir tidak ada kesenjangan antara harapan dengan kinerja. Ini berarti bahwa tahu Abian Tubuh sudah sangat memuaskan konsumen.Baik harapan maupun kinerja berada pada interval kriteria sangat tinggi.

3. Warna Produk

Pada atribut warna terdapat kesenjangan antara harapan dan kenyataan pada produk.Nilai harapan dan kinerja pada unsur ini dalam tabel berikut.

Tabel 4.11. Harapan Konsumen Kinerja Aktual pada Warna Tahu Abian Tubuh

\begin{tabular}{|c|l|c|c|c|c|c|}
\hline \multirow{2}{*}{ No } & \multirow{2}{*}{ Keterangan } & \multirow{2}{*}{ Skor } & \multicolumn{2}{c|}{ Harapan } & \multicolumn{2}{c|}{ Kinerja } \\
\cline { 4 - 7 } & & & Absolut & Jumlah & Absolut & Jumlah \\
\hline 1 & Sangat setuju & 5 & 30 & 150 & 25 & 125 \\
\hline 2 & Setuju & 4 & 25 & 100 & 15 & 60 \\
\hline 3 & Netral & 3 & 25 & 75 & 10 & 30 \\
\hline 4 & Tidak setuju & 2 & 20 & 40 & 25 & 50 \\
\hline 5 & $\begin{array}{l}\text { Sangat tidak } \\
\text { setuju }\end{array}$ & 1 & 0 & 0 & 25 & 25 \\
\hline \multicolumn{2}{|c|}{ Jumlah } & & $\mathbf{1 0 0}$ & $\mathbf{3 6 5}$ & $\mathbf{1 0 0}$ & $\mathbf{2 9 0}$ \\
\hline \multicolumn{2}{|c|}{ Kriteria } & \multicolumn{2}{c|}{ Tinggi } & \multicolumn{2}{c|}{ Kurang Tinggi } \\
\hline
\end{tabular}

Sumber: data primer diolah

Pada atribut warna terdapat kesenjangan antara harapan dengan kinerja produk yaitu 3,65>2,90, yang berarti terdapat selisih sebesar 0,75, sehingga warna tahu belum memenuhi harapan konsumen. Konsumen menginginkan agar warna produk asli atau tidak menggunakan zat pewarna kimia. Kalaupun menggunakan zat pewarna, supaya menggunakan pewarna alami, misalnya kunyit.

4. Aroma Produk

Peranan dalam produk tahu sangat penting karena turut menentukan daya terima konsumen terhadap produk tersebut.Aroma tahu tidak hanya ditentukan oleh satu komponen bahan tetapi merupakan perpaduan dari bahan-bahan pembentuknya. Aroma akan menjadi indikator rasa tahu, nilai harapan konsumen dan persepsi konsumen atas kinerja produk dapat dilihat dalam tabel berikut. 


\section{NATIONALLY ACCREDITED JOURNAL - DECREE NO. 21/E/KPT/2018}

Tabel 4.12. Harapan Konsumen Kinerja Aktual pada Aroma Tahu Abian Tubuh

\begin{tabular}{|c|l|c|c|c|c|c|}
\hline \multirow{2}{*}{ No } & \multirow{2}{*}{ Keterangan } & \multirow{2}{*}{ Skor } & \multicolumn{2}{c|}{ Harapan } & \multicolumn{2}{c|}{ Kinerja } \\
\cline { 4 - 7 } & & Absolut & Jumlah & Absolut & Jumlah \\
\hline 1 & Sangat setuju & 5 & 45 & 225 & 47 & 235 \\
\hline 2 & Setuju & 4 & 34 & 136 & 28 & 112 \\
\hline 3 & Netral & 3 & 14 & 42 & 17 & 51 \\
\hline 4 & Tidak setuju & 2 & 7 & 14 & 8 & 16 \\
\hline 5 & $\begin{array}{l}\text { Sangat tidak } \\
\text { setuju }\end{array}$ & 1 & 0 & 0 & 0 & 0 \\
\hline \multicolumn{2}{|c|}{ Jumlah } & $\mathbf{1 0 0}$ & $\mathbf{4 1 7}$ & $\mathbf{1 0 0}$ & $\mathbf{4 1 4}$ \\
\hline \multicolumn{2}{|c|}{ Kriteria } & \multicolumn{2}{c|}{ Sangat Tinggi } & \multicolumn{2}{c|}{ Sangat Tinggi } \\
\hline
\end{tabular}

Sumber: data primer diolah

Dalam tabel di atas nilai harapan konsumen pada aroma tahu sebesar 4,17, sedangkan kinerja tahu 4,14. Hampir tidak terdapat kesenjangan yang berarti sehingga dikatakan bahwa kinerja produk telah memenuhi harapan konsumen. Tidak adanya kesenjangan pada atribut aroma bisa disebabkan oleh karena industri telah melakukan proses produksi yang bersih, dengan kualitas bahan lebih baik dan output yang lebih fresh.

5. Bentuk Produk

Bentuk tahu adalah atribut yang paling mudah dikenali oleh indra penglihatan. Bentuk tahu Abian Tubuh ada yang besar dan sedang sehingga dapat menjadi pilihan bagi konsumen sesuai dengan harapannya.Pada atribut ini terdapat kesenjangan antara nilai harapan dan kinerja sebagaimana dilihat dalam tabel.

Tabel 4.13. Harapan Konsumen Kinerja Aktual pada Bentuk Tahu Abian Tubuh

\begin{tabular}{|c|l|c|c|c|c|c|}
\hline \multirow{2}{*}{ No } & \multirow{2}{*}{ Keterangan } & \multirow{2}{*}{ Skor } & \multicolumn{2}{c|}{ Harapan } & \multicolumn{2}{c|}{ Kinerja } \\
\cline { 4 - 7 } & & & Absolut & Jumlah & Absolut & Jumlah \\
\hline 1 & Sangat setuju & 5 & 0 & 0 & 25 & 125 \\
\hline 2 & Setuju & 4 & 20 & 80 & 25 & 100 \\
\hline 3 & Netral & 3 & 25 & 75 & 30 & 90 \\
\hline 4 & Tidak setuju & 2 & 30 & 60 & 10 & 20 \\
\hline 5 & $\begin{array}{l}\text { Sangat tidak } \\
\text { setuju }\end{array}$ & 1 & 25 & 25 & 10 & 10 \\
\hline \multicolumn{2}{|c|}{ Jumlah } & & $\mathbf{1 0 0}$ & $\mathbf{2 4 0}$ & $\mathbf{1 0 0}$ & $\mathbf{3 4 5}$ \\
\hline \multicolumn{2}{|c|}{ Kriteria } & \multicolumn{2}{c|}{ Rendah } & \multicolumn{2}{c|}{ Tinggi } \\
\hline
\end{tabular}

Sumber: data primer diolah Tabel. 


\section{NATIONALLY ACCREDITED JOURNAL - DECREE NO. 21/E/KPT/2018}

Hasil analisis menunjukkan bahwa nilai harapan bentuk tahu sebesar 2,40 (kriteria rendah) dan nilai kinerja sebesar 3,45 (kriteria tinggi). Ini berarti bahwa kinerja produk melampaui harapan konsumen dengan gap 1,05. Konsumen tidak berharap banyak pada bentuk tahu, pilihan bentuk yang ada sekarang sudah memenuhi harapan mereka.

6. Tekstur Produk

Tekstur adalah tanggapan konsumen terhadap permukaan produk tahu yang dapat dirasakan dengan meraba permukaan tahu.Indikator tekstur yang memenuhi harapan konsumen tahu adalah tekstur yang lembut, halus, kenyal, tidak terlalu lembek/keras.Adapun tanggapan konsumen dapat dilihat dalam tabel berikut.

Tabel 4.14. Harapan Konsumen Kinerja Aktual pada Tekstur Tahu Abian Tubuh

\begin{tabular}{|c|l|c|c|c|c|c|}
\hline \multirow{2}{*}{ No } & \multirow{2}{*}{ Keterangan } & \multirow{2}{*}{ Skor } & \multicolumn{2}{c|}{ Harapan } & \multicolumn{2}{c|}{ Kinerja } \\
\cline { 4 - 7 } & & & Absolut & Jumlah & Absolut & Jumlah \\
\hline 1 & Sangat setuju & 5 & 50 & 250 & 35 & 175 \\
\hline 2 & Setuju & 4 & 40 & 160 & 32 & 128 \\
\hline 3 & Netral & 3 & 7 & 21 & 17 & 51 \\
\hline 4 & Tidak setuju & 2 & 3 & 6 & 10 & 20 \\
\hline 5 & $\begin{array}{l}\text { Sangat tidak } \\
\text { setuju }\end{array}$ & 1 & 0 & 0 & 6 & 6 \\
\hline \multicolumn{2}{|c|}{ Jumlah } & & $\mathbf{1 0 0}$ & $\mathbf{4 3 7}$ & $\mathbf{1 0 0}$ & $\mathbf{3 8 0}$ \\
\hline \multicolumn{2}{|c|}{ Kriteria } & \multicolumn{2}{c|}{ Sangat tinggi } & \multicolumn{2}{c|}{ Tinggi } \\
\hline
\end{tabular}

Sumber: data primer diolah

Data di atas menunjukkan bahwa nilai harapan pada atribut tekstur adalah 4,37 atau kriteria sangat tinggi. Ini berarti bahwa sangat tinggi harapan konsumen pada atribut ini, namun kenyataannya produk ini menurut persepsi konsumen baru menawarkan kinerja sebesar 3,80 (tinggi) dengan selisih nilai sebesar 0,57.

7. Kandungan Gizi Produk

Kandungan gizi adalah persepsi konsumen tentang zat/vitamin yang terdapat pada produk tahu Abian Tubuh.Pada atribut ini harapan dan kinerja produk dapat dijelaskan melalui tabel berikut.

Tabel 4.15. Harapan Konsumen Kinerja Aktual pada Kandungan Gizi Tahu Abian Tubuh

\begin{tabular}{|c|l|c|c|c|c|c|}
\hline \multirow{2}{*}{ No } & \multirow{2}{*}{ Keterangan } & \multirow{2}{*}{ Skor } & \multicolumn{2}{|c|}{ Harapan } & \multicolumn{2}{c|}{ Kinerja } \\
\cline { 4 - 7 } & & Absolut & Jumlah & Absolut & Jumlah \\
\hline 1 & Sangat setuju & 5 & 37 & 185 & 47 & 235 \\
\hline 2 & Setuju & 4 & 30 & 120 & 39 & 156 \\
\hline 3 & Netral & 3 & 18 & 54 & 10 & 30 \\
\hline
\end{tabular}




\begin{tabular}{|c|l|c|c|c|c|c|}
\hline \multirow{2}{*}{ No } & \multirow{2}{*}{ Keterangan } & \multirow{2}{*}{ Skor } & \multicolumn{2}{c|}{ Harapan } & \multicolumn{2}{c|}{ Kinerja } \\
\cline { 3 - 7 } & & Absolut & Jumlah & Absolut & Jumlah \\
\hline 4 & Tidak setuju & 2 & 10 & 20 & 4 & 8 \\
\hline 5 & $\begin{array}{l}\text { Sangat tidak } \\
\text { setuju }\end{array}$ & 1 & 5 & 5 & 0 & 0 \\
\hline \multicolumn{2}{|c|}{ Jumlah } & 100 & 384 & 100 & 429 \\
\hline \multicolumn{2}{|c|}{ Kriteria } & \multicolumn{2}{|c|}{ Tinggi } & \multicolumn{2}{c|}{ Sangat Tinggi } \\
\hline
\end{tabular}

Sumber: data primer diolah

Dari tabel diketahui bahwa nilai harapan konsumen terhadap kandungan gizi sebesar 3,84 (tinggi), namun kenyataan kinerja yang diberikan produk lebih tinggi dari harapan yaitu sebesar 4,29 (sangat tinggi). Konsumen percaya bahwa gizi yang terkandung dalam produk tahu sangat tinggi sehingga konsumen yakin tidak ada masalah dengan atribut yang satu ini.

Keseluruhan tabel harapan dan kinerja diatas ditampilkan dalam sebuah tabel berikut:

Tabel 4.16. Harapan Konsumen dan Kinerja Produk Tahu Abian Tubuh

\begin{tabular}{|c|l|c|c|c|c|}
\hline No & \multicolumn{1}{|c|}{ Atribut } & Kinerja & Kriteria & Harapan & Kriteria \\
\hline 1 & Harga & 425 & $\begin{array}{c}\text { Sangat } \\
\text { Tinggi }\end{array}$ & 365 & Tinggi \\
\hline 2 & Cita Rasa & 426 & $\begin{array}{c}\text { Sangat } \\
\text { Tinggi }\end{array}$ & 432 & $\begin{array}{c}\text { Sangat } \\
\text { Tinggi }\end{array}$ \\
\hline 3 & Warna & 290 & $\begin{array}{c}\text { Kurang } \\
\text { Tinggi }\end{array}$ & 365 & Tinggi \\
\hline 4 & Aroma & 414 & Tinggi & 417 & Tinggi \\
\hline 5 & Bentuk & 345 & Tinggi & 240 & Rendah \\
\hline 6 & Tekstur & 380 & Tinggi & 437 & $\begin{array}{c}\text { Sangat } \\
\text { Tinggi }\end{array}$ \\
\hline 7 & $\begin{array}{l}\text { Kandungan } \\
\text { Gizi }\end{array}$ & 429 & $\begin{array}{c}\text { Sangat } \\
\text { Tinggi }\end{array}$ & 384 & Tinggi \\
\hline & Total & $\mathbf{2 7 0 9}$ & & $\mathbf{2 6 4 0}$ & \\
\hline & Rata - Rata & $\mathbf{3 8 7}$ & Tinggi & $\mathbf{3 7 7}$ & Tinggi \\
\hline
\end{tabular}

Sumber: data primer diolah

Dari data tabel di atas beberapa atribut yang memiliki kinerja sangat tinggi adalah kandungan gizi dengan skor 4,29, cita rasa 4,26, dan harga 4,25. Atribut yang memiliki kinerja dengan kriteria tinggi adalah aroma dengan skor 4,14, tekstur 3,80, dan bentuk 3,45. Satusatunya atribut yang mempunyai kinerja kurang tinggi adalah warna dengan skor 2,90. Nilai rata-rata kinerja adalah 3,87 dengan kriteria tinggi. Data kinerja di atas menjelaskan bahwa tahu Abian Tubuh telah menawarkan kinerja yang tinggi pada keseluruhan atribut yang diukur. 


\section{NATIONALLY ACCREDITED JOURNAL - DECREE NO. 21/E/KPT/2018}

Adapun harapan konsumen dengan kriteria sangat tinggi terletak pada atribut tekstur dengan skor 4,37 dan cita rasa 4,32. Atribut yang mempunyai harapan tinggi adalah pada aroma dengan skor 4,17, kemudian kandungan gizi 3,84, harga dan warna masing-masing sebesar 3,65. Ada satu atribut dimana konsumen memiliki harapan yang rendah yaitu pada bentuk tahu dengan nilai 2,40. Rata-rata nilai harapan konsumen adalah 3,77 yang berarti konsumen mempunyai harapan tinggi pada atribut produk tahu Abian Tubuh.

\subsection{Analisis Indeks Kepuasan Konsumen (IKK)}

Analisis ini digunakan untuk mengukur sejauh mana kinerja atribut produk sudah memenuhi harapan konsumen, dengan cara membandingkan nilai kinerja setiap atribut produk dengan nilai harapannya. Perbandingan ini dapat dilihat dalam tabel berikut.

Tabel 4.17. Kriteria Kesesuaian/Perbandingan Harapan dan Kinerja Aktual Atribut Produk Tahu Abian Tubuh

\begin{tabular}{|c|l|c|c|c|c|}
\hline No & \multicolumn{1}{|c|}{ Atribut } & Kinerja & Harapan & IKK & Kriteria \\
\hline 1 & Harga & 425 & 365 & 1,16 & Sangat puas \\
\hline 2 & Cita Rasa & 426 & 432 & 0,98 & Puas \\
\hline 3 & Warna & 290 & 365 & 0,84 & Kurang puas \\
\hline 4 & Aroma & 414 & 417 & 0,99 & Puas \\
\hline 5 & Bentuk & 345 & 240 & 1,43 & Sangat puas \\
\hline 6 & Tekstur & 380 & 437 & 0,88 & Kurang puas \\
\hline 7 & $\begin{array}{l}\text { Kandungan } \\
\text { Gizi }\end{array}$ & 429 & 384 & 1,12 & Sangat puas \\
\hline \multicolumn{2}{r|}{ Rata - Rata } & 387 & 377 & $\mathbf{1 , 0 6}$ & Puas \\
\hline
\end{tabular}

Sumber: data primer diolah

Dari tabel di atas diketahui rata-rata skor kinerja atribut produk sebesar 387 dan ratarata nilai harapan sebesar 377.Ada terdapat selisih yang kecil antara nilai kinerja dengan harapan sebesar 10. Walaupun ada selisih namun tidak memberi arti terhadap nilai IKK yaitu sebesar 1,06, atau dibulatkan menjadi 1 (kategori konsumen puas). Tabel di atas juga menjelaskan sejumlah atribut yang telah memenuhi harapan konsumen dengan IKK $>1$ yaitu bentuk tahu, harga, dan kandungan gizi. Atribut lain, IKK nya mendekati 1 dan lebih kecil dari 1 yaitu aroma, cita rasa, tekstur, dan atribut warna.

Atribut bentuk tahu paling memenuhi harapan konsumen karena IKK nya paling besar yaitu 1,43. Namun dalam kenyataannya, konsumen tidak memiliki harapan yang tinggi terhadap bentuk tahu. Kriteria harapan dalam atribut ini adalah rendah karena skor 2,40 berada pada interval 1,80-2,59. Dengan kata lain, konsumen tidak terlalu mempermasalahkan bentuk dalam menentukan kepuasan dan ketidakpuasannya terhadap tahu.

Harga tahu merupakan atribut kedua yang memenuhi harapan konsumen. Nilai IKK sebesar 1,16 menunjukkan bahwa konsumen setuju bahwa atribut harga telah memenuhi harapan. Konsumen memiliki nilai harapan yang tinggi pada unsur ini, namun produk tahu 
Abian Tubuh sudah menawarkan kinerja harga yang lebih tinggi dari harapan, dengan kriteria kinerja sangat tinggi karena skor 3,25 berada pada interval 4,2-5,0.

Kandungan gizi telah memenuhi harapan konsumen.Kriteria harapan pada atribut adalah tinggi, sedangkan kinerja sangat tinggi. Ini berarti bahwa meskipun konsumen telah dipenuhi harapannya pada unsur kandungan gizi, namun sebetulnya skor harapan konsumen 3,84 berada di interval kedua yaitu pada 3,4-4,19 atau harapannya tidak sangat tinggi pada atribut ini.

Aroma produk mempunyai skor kinerja yang mendekati skor harapan, sehingga IKK mendekati 1. Nilai harapan maupun kinerja aroma produk berada pada batas atas interval 3,4-4,19 dengan kriteria tinggi. Konsumen setuju bahwa aroma produk hampir memenuhi harapannya.Namun demikian, karena atribut ini mempunyai skor harapan yang tinggi, itu merupakan indikasi pentingnya kinerja produk minimal memenuhi harapan konsumen.

Tidak berbeda dengan aroma, cita rasa produk tahu mempunyai skor kinerja yang mendekati skor harapan, yakni mendekati 1 . Lebih dari itu posisi nilai IKK kinerja dan harapan bahkan berada pada interval 4,2-5,0 atau kriteria sangat tinggi. Dengan kata lain konsumen mempunyai harapan sangat tinggi pada aspek cita rasa tahu Abian Tubuh, dan sudah hampir terpenuhi oleh kinerja produk saat ini. Dari keseluruhan atribut yang diukur, hanya cita rasa merupakan atribut yang mempunyai skor kinerja maupun harapan dengan kriteria sangat tinggi.

Tekstur mempunyai skor harapan sangat tinggi, tetapi kinerjanya belum mencapai harapan.Konsumen berpendapat mereka lebih menyukai tahu yang memiliki tekstur kenyal dan lembut, aroma lezat yang berpengaruh pada rasa tahu.Tahu merupakan produk makanan yang cepat rusak, cepat berubah pada rasa, tekstur, dan aroma, idealnya harus cepat dikonsumsi.Oleh karena itu pengendalian pasca produksi menjadi penting agar produk akhir yang sampai ke konsumen dalam kondisi fresh dan baik.

Atribut terakhir, yaitu warna merupakan atribut yang mempunyai skor harapan tinggi namun kinerjanya rendah.Konsumen menginginkan tahu yang tidak menggunakan bahan pewarna pewarna buatan (kimia), menambah variasi warna dengan pewarna alami (kunyit).

\subsection{Analisis Diagram Kartesius}

Pengukuran dengan menggunakan diagram kartesius dimaksudkan untuk mengetahui atribut mana yang perlu diperbaiki secara prioritas pada produk tahu Abian Tubuh. Pengukuran ini biasanya dilakukan dengan menentukan skor setiap atribut dan ratarata skor atribut pada harapan dan kinerja produk.

Tabel 4.18. Rata-rata Nilai Kinerja dan Harapan Konsumen Produk Tahu Abian Tubuh

\begin{tabular}{|c|l|c|c|c|c|}
\hline No & \multicolumn{1}{|c|}{ Atribut } & $\begin{array}{c}\text { Penilaian } \\
\text { Kinerja } \\
(\mathbf{X})\end{array}$ & $\begin{array}{c}\text { Penilaian } \\
\text { Harapan } \\
(\mathbf{Y})\end{array}$ & $\mathbf{X}$ & $\mathbf{Y}$ \\
\hline 1 & Harga & 425 & 365 & 4,25 & 3,65 \\
\hline 2 & Cita Rasa & 426 & 432 & 4,26 & 4,32 \\
\hline 3 & Warna & 290 & 365 & 2,90 & 3,65 \\
\hline 4 & Aroma & 414 & 417 & 4,14 & 4,17 \\
\hline 5 & Bentuk & 345 & 240 & 3,45 & 2,40 \\
\hline 6 & Tekstur & 380 & 437 & 3,80 & 4,37 \\
\hline
\end{tabular}




\begin{tabular}{|c|l|c|c|c|c|}
\hline 7 & $\begin{array}{l}\text { Kandungan } \\
\text { Gizi }\end{array}$ & 429 & 384 & 4,29 & 3,84 \\
\hline \multicolumn{3}{|c|}{ Total } & $\mathbf{2 7 , 0 9}$ & $\mathbf{2 6 , 4 0}$ \\
\hline \multicolumn{3}{|c|}{ Rata - Rata } & 3,87 & $\mathbf{3 , 7 7}$ \\
\hline
\end{tabular}

Sumber: data primer diolah

Pada tabel di atas diketahui nilai rata-rata kinerja dan harapan konsumen tahu Abian Tubuh, yaitu masing-masing 3,87 dan 3,77. Data rata-rata tersebut diplot pada diagram yang terdiri dari empat kuadran, dimana sumbu $X$ untuk kinerja aktual, dan sumbu $Y$ untuk harapan konsumen.

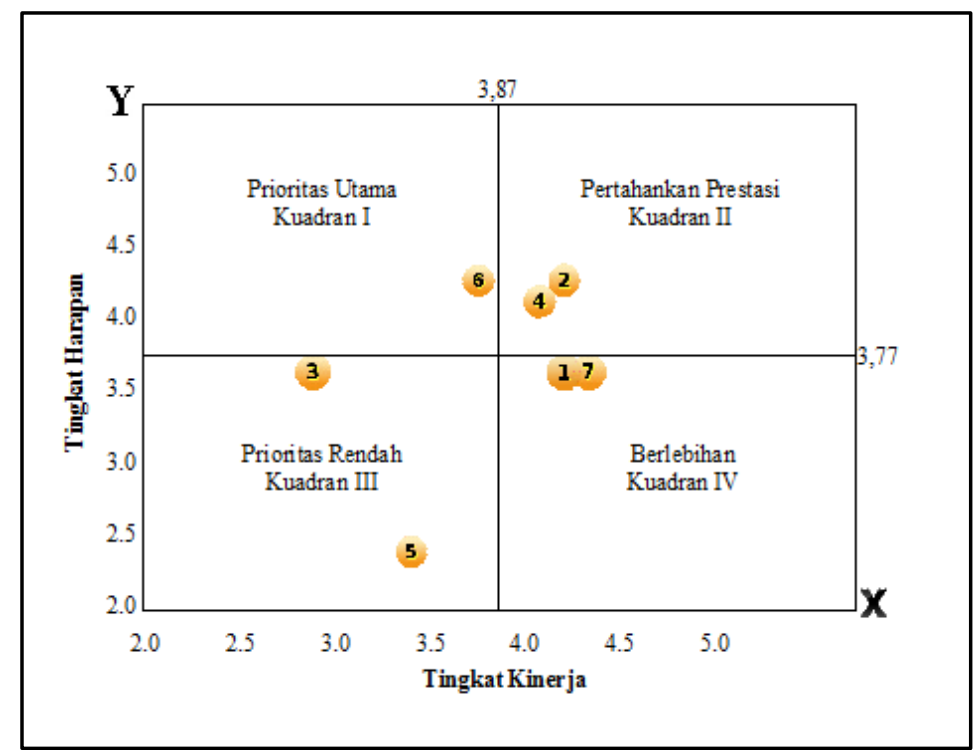

Gambar 4.1. Analisis Diagram Kartesius

Pada diagram di atas diketahui bahwa atribut-atribut produk tersebar pada setiap kuadran, ada atribut yang perlu diperbaiki, dipertahankan, dan ditingkatkan.

1. Kuadran I (Prioritas Utama)

Atribut yang berada pada kuadran I menunjukkan atribut yang memiliki nilai harapan tinggi, tetapi nilai kinerja rendah.Atribut ini perlu mendapat perhatian khusus atau diprioritaskan karena dinilai sangat penting oleh konsumen. Atribut tersebut adalah tekstur tahu Konsumen berpendapat mereka lebih menyukai tahu yang memiliki tekstur kenyal dan lembut karena akan berpengaruh pada rasa tahu. Tahu merupakan produk makanan yang cepat rusak, cepat berubah pada rasa, tekstur, dan aroma, idealnya harus terdistribusi dengan tepat dan cepat.Pengendalian pasca produksi akhirnya menjadi penting agar produk akhir yang sampai ke konsumen dalam kondisi fresh dan baik.

2. Kuadran II (Pertahankan Prestasi)

Pada kuadran II terdapat atribut yang dianggap penting oleh konsumen artinya konsumen memiliki harapan yang tinggi, tetapi produk juga telah menawarkan kinerja yang tinggi pada atribut-atributnya.Ada dua atribut terdapat dalam kuadran ini yaitu cita rasa dan aroma.Konsumen sudah merasa puas dengan cita rasa dan aroma produk tahu Abian Tubuh, karena menurut mereka selain memiliki aroma yang enak, rasa tahu ini lezat dan lembut di lidah.Produsen perlu mempertahankan kinerja produk tetap berada pada kuadran ini. 


\section{Jurnal Magister Manajemen Unram ～Vol. 9, No 2. Juni 2020 NATIONALLY ACCREDITED JOURNAL - DECREE NO. 21/E/KPT/2018}

\section{Kuadran III (Perbaikan)}

Tingkat harapan dan kinerja produk pada kuadran ini rendah, artinya konsumen memiliki harapan yang rendah pada atribut ini, tetapi juga produk tahu Abian Tubuh juga belum menawarkan kinerja yang baik pada atribut tersebut.Atribut-atribut yang menempati kuadran ini adalah warna dan bentuk produk.Dalam konteks warna, konsumen memiliki harapan untuk menambah jenis warna dengan menggunakan pewarna alami (kunyit), namun mereka tidak terlalu mempermasalahkan bentuk dalam menentukan kepuasan dan ketidakpuasannya terhadap tahu.Namun demikian, kualitas atribut-atribut itu perlu perbaikan.

4. Kuadran IV (Berlebih)

Harapan konsumen terhadap suatu atribut dalam kuadran ini rendah, namun kinerja aktualnya tinggi.Ada dua atribut yang masuk dalam kategori ini yaitu harga dan kandungan gizi. Menurut konsep diagram kartesius, konsumen memiliki harapan/kepentingan yang rendah pada atribut harga dan kandungan gizi tahu Abian Tubuh, tetapi produsen telah menawarkan kinerja yang dinilai berlebihan pada kedua atribut tersebut.

\section{KESIMPULAN DAN SARAN}

\subsection{Kesimpulan}

Berdasarkan hasil penelitian Analisis Kepuasan Konsumen produk Tahu Abian Tubuh dapat ditarik kesimpulan sebagai berikut:

1. Dari analisis Indeks Kepuasan Konsumen (IKK) menunjukkan bahwa konsumen merasa "PUAS" atas produk tahu Abian Tubuh. Hal ini ditunjukkan oleh total skor kinerja atribut produk sama dengan total skor harapan konsumen sehingga dapat dikatakan konsumen merasa "PUAS".

2. Dari analisis Diagram Kartesius, masing-masing atribut memiliki nilai kepuasan berbeda. Ada satu atribut yang memiliki nilai harapan tinggi, tetapi nilai kinerja rendah yaitu tekstur tahu. Atribut ini harus mendapat perhatian khusus karena dianggap penting oleh konsumen. Konsumen lebih menyukai tahu yang memiliki tekstur lebih kenyal dan lembut. Tahu merupakan produk makanan yang cepat rusak, cepat berubah pada rasa, tekstur, dan aroma, kalau tidak terdistribusi dengan tepat dan cepat.

3. Penggunaaan pendekatan IKK dan diagram kartesius menghasilkan perbedaan penafsiran pada atribut harga dan gizi. Pendekatan diagram kartesius menunjukkan atribut harga dan kandungan gizi memiliki kinerja yang dinilai berlebihan. Namun, pendekatan Indeks Kepuasan Konsumen (IKK) untuk kedua atribut menghasilkan IKK yang tinggi, artinya bahwa konsumen merasa sudah sangat puas dengan harga dan kandungan gizi tahu Abian Tubuh saat ini. Artinya, penggunaan kedua pendekatan di atas saling melengkapi. Kelemahan pada satu alat, ditutupi oleh pendekatan lainnya.

\subsection{Implikasi Manajerial}

Bertolak dari hasil penelitian menggunakan analisis IKK dan diagram kartesius diatas, maka dapat diajukan saran kepada produsen pada industri tahu Abian Tubuh sebagai berikut:

1. Produsen industri tahu Abian Tubuh harus melakukan aktivitas pengendalian pasca produksi, seperti distribusi yang cepat dan tepat agar produk akhir yang sampai ke konsumen dalam kondisi fresh dan baik.

2. Konsumen memiliki harapan tinggi terhadap kinerja atribut citarasa, aroma, dan tekstur produk tahu Abian Tubuh, oleh karena itu atribut-atribut tersebut harus mendapatkan perhatian khusus. 


\section{Jurnal Magister Manajemen Unram ～Vol. 9, No 2. Juni 2020 \\ NATIONALLY ACCREDITED JOURNAL - DECREE NO. 21/E/KPT/2018}

\section{DAFTAR PUSTAKA}

Cahyadi, W. 2007.Kedelai Khasiat dan Teknologi.Jakarta. Bumi Aksara.

Djarwanto dan Subagyo, Pangestu. 2006. Statistik Induktif. Yogyakarta. BPFE UGM.

Guilford, J.P and Fruchter B. 1987.Fundamental Statistik In Psychology and. Education, Fifth Edition. McGraw-Hill. Kogakusha, Ltd.

Ilhamuddin. 2018. Sikap Konsumen Terhadap Produk Tahu Abian Tubuh sebagai produk unggulan sektor makanan Kota Mataram. JMM Universitas Mataram.

Kotler, Phillip dan Kevin L. Keller. 2016. Marketing Management. 16 ${ }^{\text {th }}$ Edition. New Jersey. Pearson.

Lapiyodi, Rambat dan Hamdani. 2006. Manajemen Pemasaran Jasa. Jakarta. Salemba Empat.

Nasution. 2004. Manajemen Jasa Terpadu. Jakarta. Ghalia Indonesia.

Nazir, Muh. 2005. Metode Penelitian. Bogor. Ghalia Indonesia.

Nurkandi, Mia. 2009. Anilisis Secara Biokimia Methanyl Yellow pada Tahu yang Beredar di Pasar Kodya Bandung. Prosiding Seminar Nasional Penelitian, Pendidikan dan Penerapan MIPA, Fakultas MIPA, Universitas Negeri Yogyakarta, 16 Mei 2009.

Sugiyono, 2010.Metode Penelitian Bisnis. Bandung. Alfabeta.

Sumarwan, Ujang. 2011. Perilaku Konsumen: Teori dan Penerapannya dalam Pemasaran. Jakarta. Ghalia Indonesia.

Supranto.2011. Pengukuran Tingkat Kepuasan Pelayanan untuk Menaikkan Pangsa Pasar. Jakarta. Rineka Cipta.

Surakhmad.1998. Metode Penelitian Sosial. Bandung.PT. Remadja Rosdakarya.

Tjiptono, Fandy. 2001. Manajemen Jasa. Yogyakarta. Andi Offset.

Wibisono, Dermawan. 2003. Riset Bisnis. Jakarta. PT. Gramedia Pustaka Utama.

Surat Keputusan Walikota Mataram Nomor 526/X/2009 tentang Penetapan Klaster Industri Kecil Unggulan Kota Mataram

www.bps.go.id 